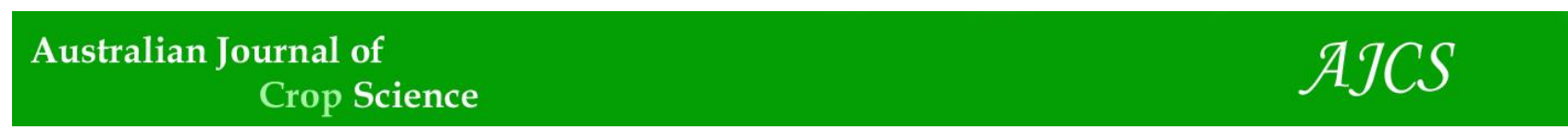

AJCS 11(12):1609-1616 (2017)

ISSN:1835-2707

doi: 10.21475/ajcs.17.11.12.pne795

\title{
Production components and water use efficiency of corn under irrigation depths
}

Franklin Alves dos Anjos ${ }^{1}$, Carlos Alberto Vieira de Azevedo ${ }^{2,4}$, Rener Luciano de Souza Ferraz ${ }^{2 *}$,
José Leonaldo de Souza ${ }^{3}$, Vera Lúcia Antunes de Lima ${ }^{2,5}$, Constantino Antônio Cavalcante Júnior ${ }^{2}$

${ }^{1}$ Federal Institute of Education, Science and Technology of Alagoas, Santana do Ipanema, 57.500-000, Alagoas,

Brazil

${ }^{2}$ Federal University of Campina Grande, Academic Unit of Agricultural Engineering, Campina Grande, 58.109970, Paraíba, Brazil

${ }^{3}$ Federal University of Alagoas, Crop Production Department, Maceió, 57.072-900, Alagoas, Brazil

${ }^{4}$ Fellow of CNPq Research Productivity, level 1B, Brazil

${ }^{5}$ Fellow of CNPq Research Productivity, level 1D, Brazil

*Corresponding author: ferragroestat@gmail.com

\begin{abstract}
This study aims to analyze the production components and the water-use efficiency of corn cultivated with irrigation depths, and also to verify the utilization of multivariate analysis is suitable to highlight the relevant information. Hybrid corn AG 7088 was used as plant material. Two experiments were conducted under field conditions at two different experimental periods between the months of April and December 2015 in a randomized block design with six irrigation depths [50, 75, 100 (control), 125, 150, and 175\% replacement of evapotranspiration - $\mathrm{ET}_{0}$ ] and four replications. At 120 days after sowing, the following variables were evaluated: mass of one thousand grains, number of spikes per plot, yield of dry grains, ear length, ear diameter, number of lines per ear, number of grains per line, number of ears grain per spike, grain mass per spike, cob mass, spaghetti mass, and mass of straws. The results showed that production components and water use efficiency of hybrid corn AG 7088 were not affected by the varying water depths in the first experimental period. In the second period, the increase in water depth supported a gain in the mass of a thousand grains, dry grain yield, grain number per row, grain number per ear, corn cob mass and mass of dehusked ear, reducing the efficiency of water use. The use of multivariate analysis was able to reduce the multi-dimensional space of the set of variables in the three Principal Components with relevant information to highlight differences between irrigation depths and experimental periods.
\end{abstract}

Keywords: Zea mays L., productivity, water management, principal components.

Abbreviations: PCA_principal component analysis; Rg_global radiation; PAR_photosynthetically active radiation; Rn_radiation balance, and PP_rainfall, $\mathrm{ET}_{0} \_$reference evapotranspiration; $\mathrm{mH}_{2} \mathrm{O} \_$meters of water column; DAS_days after sowing; MTG_mass of a thousand grains; ENP_ear number per plot; DGY_dry grain yield; EAL_ear length; EAD_ear diameter; RNE_row number per ear; GNR_grain number per row; GNE_grain number per ear; GME_grain mass per ear; CMA_corn cob mass; MDE_mass of dehusked

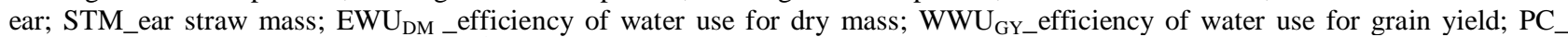
principal component; $\lambda$ _eigenvalues; $\sigma^{2} \_$variance; $\mathrm{CO}_{2}$ _carbon dioxide; $\mathrm{NADP}^{+}{ }_{-}$Nicotinamide adenine dinucleotide phosphate; ROS_reactive oxygen species; ATO_Adenosine triphosphate; RuBP_ribulose-1,5-bisphosphate.

\section{Introduction}

Among the cultivated species, corn (Zea mays L.) portrays itself as a prominent crop on the world stage, notably because of its multiplicity of use, from food and feed to the high-tech industry and its use in the production of biofuels. Corn is highlighted as a crop of significant economic importance in the world's agribusiness (Ribeiro et al., 2015). Corn is cultivated in almost the entire Brazilian national territory, which is justified by its high production potential (Silva et al., 2015; $\mathrm{Li}$ and Sun, 2016). In fact, the crop is very efficient in the use of production factors, even in restrictive environments, due to its well-adapted photosynthetic apparatus. The culture belongs to the group of plants with photosynthetic metabolism type $\mathrm{C} 4$, which gives it a high uptake capacity and carbon dioxide assimilation (Dantas Júnior et al., 2011). Silva et al. (2015) reported that the water availability in the Brazilian Northeast is a limiting factor for agricultural production due to its low rainfall. This region is characterized by irregularities in the spatial and temporal distribution of rainfall. Under these conditions, water deficit is one of the factors responsible for low crop yields in these semiarid regions. This deserves emphasis in relation to the development of promising strategies to mitigate its negative effect (Alderfasi et al., 2016; Wu et al., 2017).

The choice of hybrids that adapt to soil and climatic conditions of cultivation is an important strategy for ensuring major crops. This information is based on the fact that the corn crop is characterized by its high water demand. It is also one of the most efficient crops in use of water (water use efficiency). It has a high ratio of dry matter production by unit of consumed water (Silva et al., 2012).

The availability of water in ideal conditions promotes the maintenance of soil moisture at an optimal level for the crop, ensuring its growth and full development (Xavier et al., 2014). In this context, appropriate irrigation has often been 
used to supply the water requirement for corn, with the aim of providing a balanced use of water and highlighting production systems involving the economic, environmental, and social aspects. It enables the conservation of natural resources, especially water resources (Silva et al., 2015).

In another aspect, identifying the differences between populations or between samples is dependent on a number of variables. For the explanation of complex phenomena, the use of a single variable can lead to results with low relevance. In fact, there are situations where the individual analysis of variables do not show the differences between treatments, while the multivariate global analysis makes the differences clear, indicating the need to respect the interdependent structure of variables. Thus, multivariate analysis must be performed whenever possible (Hair et al., 2009). The Principal Component Analysis (PCA) is effective method to reducing the dimensions of relationships (Ranamukhaarachchi et al., 2017; Yi et al., 2017).

The objectives of this study are to analyze the production components and the efficiency of water use by corn, in response to the application of irrigation depths, and also to check whether the use of multivariate data analysis is efficient to highlight the differences and reduce the original dimensions of the data, with relevant information for this study.

\section{Results}

\section{Analysis of variance}

Based on the results of the analysis of variance, we found that there was no significant difference between irrigation depths $(p>0.05)$ for the production components studied in the first experiment (April 11, 2015 to August 11, 2015). On the other hand, in the second experiment (25/08/2015 to $25 / 12 / 2015)$, significant differences were found between the irrigation depths applied $(p<0.05)$ for the variables of row number per ear and grain number per ear. Although no significant differences were found through the F-test in the second experiment, there was a linear regression adjustment for the means of the variables: Mass of a thousand grains, dry grain yield, grain number per row, corn cob mass, mass of dehusked ears, and quadratic adjustment for grain number per ear (Table 1).

\section{Production components}

The largest accumulation of the mass of a thousand grains $(230.3 \mathrm{~g})$, dry grain yield $\left(7,563.4 \mathrm{~kg} \mathrm{ha}^{-1}\right)$, and grain number per row (33.6 units row $^{-1}$ ), were obtained within the irrigation depth of $801 \mathrm{~mm} \mathrm{cycle}^{-1}$. Increments of $24 \%, 44 \%$, and $12 \%$, respectively, were calculated for these variables in relation to plants cultivated under a critical depth of $229 \mathrm{~mm} \mathrm{cycle}^{-1}$. This water depth promoted the lower values of mass (175.4 $\mathrm{g})$, yield $\left(4,225.0 \mathrm{~kg} \mathrm{ha}^{-1}\right)$, and grains per row (29.7 units row ${ }^{1}$ ), as illustrated in Fig. 1A, B, and C.

As the irrigation depths were increased, there was a $17.2 \%$ increase in the grain number per ear, recording the most impressive value (593 units ear ${ }^{-1}$ ), with an estimated depth of

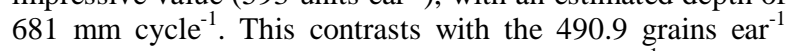
evidenced in the lowest depth $\left(229 \mathrm{~mm} \mathrm{cycle}^{-1}\right)$ applied. However, the increase of depths above $681 \mathrm{~mm} \mathrm{cycle}^{-1}$ promoted a reduction of $1 \%$ until the limit depth of the 801 $\mathrm{mm} \mathrm{cycle}{ }^{-1}$, where grains were quantified at 585.8 ear $^{-1}$ (Fig. $1 \mathrm{D})$.

The increase in water depths up to $801 \mathrm{~mm} \mathrm{cycle}^{-1}$ produced significant gains of $32 \%$ and $39 \%$ in corn cob mass and mass of the dehusked ear, being recorded at $28 \mathrm{~g}$ corn $\mathrm{cob}^{-1}$ and $188.2 \mathrm{~g} \mathrm{ear}^{-1}$, respectively, for these variables, and these percentage gains were calculated using smaller cob

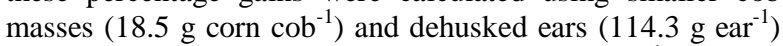
obtained from the lowest depth of $229 \mathrm{~mm} \mathrm{cycle}^{-1}$ (Fig. 1E and F).

\section{Principal components}

It was possible to reduce the multidimensional space of the original set of variables into three Principal Components (PC) with eigenvalues greater than the unity $(\lambda>1.0)$, as recommended by the Kaiser criteria, for choice of PCs. Together, the chosen components explain $88.56 \%$ of the total variance, where the first Principal Component (PC1) withholds $61.3 \%$ of the total accumulated variance. The second and third Components (PC2 and PC3) contribute with $15.2 \%$ and $12.1 \%$ of this variance, respectively. In PC1, seven variables with expressive factor loadings (r) were listed, while in PC2 and PC3 two variables stood out. In all components, the association between the expressive variables and the PC was classified as strong, according to the classification of Dancey and Reidy (2013), where: $r=|0.10|$ to $|0.30|$ (weak); $r=|0.40|$ to $|0.6|$ (moderate); $r=|0.70|$ to |1.00| (strong) (Table 2).

From the projection of the factorial scores of the first two PCs in two dimensions, it was found that $61.34 \%$ of the variance was due to the temporal variation represented by the experimental periods (E). The scores of the first experiment (first experimental period, $\mathrm{E}_{1}$ ), as well as the direction of the variables occupied positions relatively on the left side of $\mathrm{PC} 1$, whereas in the second experiment (second experimental period, $\mathrm{E}_{2}$ ) they were located on the right. In PC2, $15.16 \%$ of the variance was due to the separation between the irrigation depths (L) in the upper and lower levels. The absence of a hierarchical order between the irrigation depths in $E_{1}$ denotes the nonexistence of a significant effect from them in this period. Moreover, the fact that the larger depths $\left(\mathrm{L}_{5}\right.$ and $\left.\mathrm{L}_{6}\right)$ have a position in the upper level shows a positive influence of these on the set of variables projected on PC2 when compared to $\mathrm{L}_{1}$ (Fig. 2A and B).

In $\mathrm{PC} 3$, it can be observed that $\mathrm{L}_{3}$ was higher than other depths in $\mathrm{E}_{1}$, showing a straw mass with high discriminatory power, while at $\mathrm{E}_{2}$ the depths $\mathrm{L}_{2}$ and $\mathrm{L}_{5}$ provided greater straw mass at the expense of the ear number per plot. This last variable shows better results at depths $\mathrm{L}_{3}, \mathrm{~L}_{4}$, and $\mathrm{L}_{6}$, emphasizing the inverse relationship between these two variables of PC3 (Fig. 2C and D).

\section{Water use efficiency}

The increase of irrigation depths did not affect the water use efficiency of corn plants in the first experimental period (first experiment). Moreover, there was a significant reduction ( $p<$ $0.01)$ in $E W U_{D M}$ in the second period (second experiment), demonstrating lower biomass allocation, according to each unit of water absorbed during the cycle. It is noteworthy that the $\mathrm{EWU}_{\mathrm{GY}}$ remained unchanged regardless of the experimental period and irrigation depth (Table 3 ).

\section{Discussion}

The differences observed between the climatic conditions of the first $\left(\mathrm{E}_{1}\right)$ and second $\left(\mathrm{E}_{2}\right)$ experiments are due to the transition between the dry and rainy periods, which is a peculiar characteristic of the experimental region. In fact, this transition causes a remarkable change in the climate, 
Table 1. Summary of variance analysis for the variables: Mass of a thousand grains (MTG), ear number per plot (ENP), dry grain yield (DGY), ear length (EAL), ear diameter (EAD), row number per ear (RNE), grain number per row (GNR), grain number per ear (GNE), grain mass per ear (GME), corncob mass (CMA), mass of dehusked ear (MDE) and straw mass (STM) of corn under irrigation depths.

\begin{tabular}{|c|c|c|c|c|c|c|c|}
\hline \multirow{3}{*}{ SV } & \multirow{3}{*}{ DF } & \multicolumn{6}{|c|}{ Medium squares } \\
\hline & & \multicolumn{6}{|c|}{ First Experiment } \\
\hline & & MTG & ENP & DGY & EAL & EAD & RNE \\
\hline Depths & 5 & $106.13^{\text {ns }}$ & $9440937.60^{\mathrm{ns}}$ & $1255889.74^{\mathrm{ns}}$ & $0.53^{\mathrm{ns}}$ & $10.02^{\text {ns }}$ & $1.90^{\mathrm{ns}}$ \\
\hline Linear R. & 1 & $192.37^{\mathrm{ns}}$ & $761216.00^{\mathrm{ns}}$ & $627796.98^{\mathrm{ns}}$ & $0.80^{\mathrm{ns}}$ & $8.79^{\mathrm{ns}}$ & $1.03^{\mathrm{ns}}$ \\
\hline Quadratic R. & 1 & $146.61^{\mathrm{ns}}$ & $22788539.83^{\mathrm{ns}}$ & $497412.03^{\mathrm{ns}}$ & $5 \mathrm{E}-6^{\mathrm{ns}}$ & $1.48^{\mathrm{ns}}$ & $3.12^{\mathrm{ns}}$ \\
\hline Blocks & 3 & $210.57^{\mathrm{ns}}$ & $29599286.50^{\mathrm{ns}}$ & $1819841.37^{\mathrm{ns}}$ & $0.41^{\mathrm{ns}}$ & $12.64^{\mathrm{ns}}$ & $1.98^{\mathrm{ns}}$ \\
\hline Error & 15 & 206.11 & 19759332.60 & 1402369.74 & 0.64 & 14.05 & 1.31 \\
\hline \multirow[t]{2}{*}{$\mathrm{CV}(\%)$} & & 4.83 & 6.97 & 11.55 & 4.95 & 7.17 & 6.38 \\
\hline & & GNR & GNE & $\mathrm{GME}$ & CMA & $\mathrm{MDE}$ & STM \\
\hline Depths & 5 & $4.03^{\mathrm{ns}}$ & $3287.03^{\text {ns }}$ & $195.42^{\mathrm{ns}}$ & $11.23^{\mathrm{ns}}$ & $455.23^{\mathrm{ns}}$ & $20.13^{\mathrm{ns}}$ \\
\hline Linear R. & 1 & $12.41^{\mathrm{ns}}$ & $949.75^{\mathrm{ns}}$ & $219.43^{\mathrm{ns}}$ & $35.50^{\mathrm{ns}}$ & $1331.65^{\mathrm{ns}}$ & $54.44^{\mathrm{ns}}$ \\
\hline Quadratic R. & 1 & $0.02^{\mathrm{ns}}$ & $2964.93^{\mathrm{ns}}$ & $52.86^{\mathrm{ns}}$ & $7.81^{\mathrm{ns}}$ & $74.30^{\mathrm{ns}}$ & $0.28^{\mathrm{ns}}$ \\
\hline Blocks & 3 & $2.46^{\mathrm{ns}}$ & $4185.50^{\mathrm{ns}}$ & $156.91^{\mathrm{ns}}$ & $4.77^{\mathrm{ns}}$ & $284.70^{\mathrm{ns}}$ & $23.46^{\mathrm{ns}}$ \\
\hline Error & 15 & 3.20 & 1611.92 & 381.25 & 23.29 & 635.92 & 23.99 \\
\hline \multirow[t]{3}{*}{$\mathrm{CV}(\%)$} & & 5.70 & 7.09 & 9.42 & 11.40 & 10.22 & 13.14 \\
\hline & & \multicolumn{6}{|c|}{ Second Experiment } \\
\hline & & MTG & ENP & DGY & EAL & EAD & RNE \\
\hline Depths & 5 & $2018.70^{\mathrm{ns}}$ & $276643036.44^{\mathrm{ns}}$ & $6839977.07^{\mathrm{ns}}$ & $2.13^{\mathrm{ns}}$ & $7.74^{\mathrm{ns}}$ & $0.37^{*}$ \\
\hline Linear R. & 1 & $8450.23^{*}$ & $311139045.99^{\mathrm{ns}}$ & $31172451.87^{* *}$ & $5.15^{\mathrm{ns}}$ & $15.48^{\mathrm{ns}}$ & $0.04^{\mathrm{ns}}$ \\
\hline Quadratic R. & 1 & $535.59^{\mathrm{ns}}$ & $1343875.19^{\mathrm{ns}}$ & $303713.92^{\mathrm{ns}}$ & $2.18^{\mathrm{ns}}$ & $17.64^{\mathrm{ns}}$ & $0.45^{\mathrm{ns}}$ \\
\hline Blocks & 3 & $415.10^{\mathrm{ns}}$ & $259378252.71^{\mathrm{ns}}$ & $300225.49^{\mathrm{ns}}$ & $0.92^{\mathrm{ns}}$ & $44.31^{\mathrm{ns}}$ & $0.97^{*}$ \\
\hline Error & 15 & 1064.81 & 99635741.17 & 2520608.79 & 1.92 & 14.39 & 0.13 \\
\hline \multirow[t]{2}{*}{$\mathrm{CV}(\%)$} & & 16.08 & 17.14 & 26.93 & 9.02 & 8.79 & 2.02 \\
\hline & & GNR & GNE & GME & $\mathrm{CMA}$ & $\mathrm{MDE}$ & STM \\
\hline Depths & 5 & $11.21^{\mathrm{ns}}$ & $5899.18^{* * *}$ & $4577.32^{\mathrm{ns}}$ & $53.98^{\mathrm{ns}}$ & $5427.06^{\mathrm{ns}}$ & $424.79^{\mathrm{ns}}$ \\
\hline Linear R. & 1 & $41.27^{* *}$ & $20153.68^{* * *}$ & $11610.38^{\mathrm{ns}}$ & $254.41^{*}$ & $15301.25^{*}$ & $42.04^{\mathrm{ns}}$ \\
\hline Quadratic R. & 1 & $13.11^{\mathrm{ns}}$ & $6835.78^{*}$ & $3264.50^{\mathrm{ns}}$ & $0.02^{\mathrm{ns}}$ & $3278.94^{\mathrm{ns}}$ & $78.98^{\mathrm{ns}}$ \\
\hline Blocks & 3 & $15.08^{*}$ & $6102.68^{* *}$ & $2751.03^{\mathrm{ns}}$ & $45.02^{\mathrm{ns}}$ & $3115.63^{\mathrm{ns}}$ & $843.35^{\mathrm{ns}}$ \\
\hline Error & 15 & 4.32 & 804.77 & 2677.55 & 39.01 & 3078.85 & 577.52 \\
\hline $\mathrm{CV}(\%)$ & & 6.57 & 5.11 & 40.42 & 26.89 & 36.68 & 80.59 \\
\hline
\end{tabular}

**, * and ns: significant at 1 and 5\% and not significant by F test; SV: sources of variation; DF: degrees of freedom; R.: re gression; and CV: coefficient of variation.
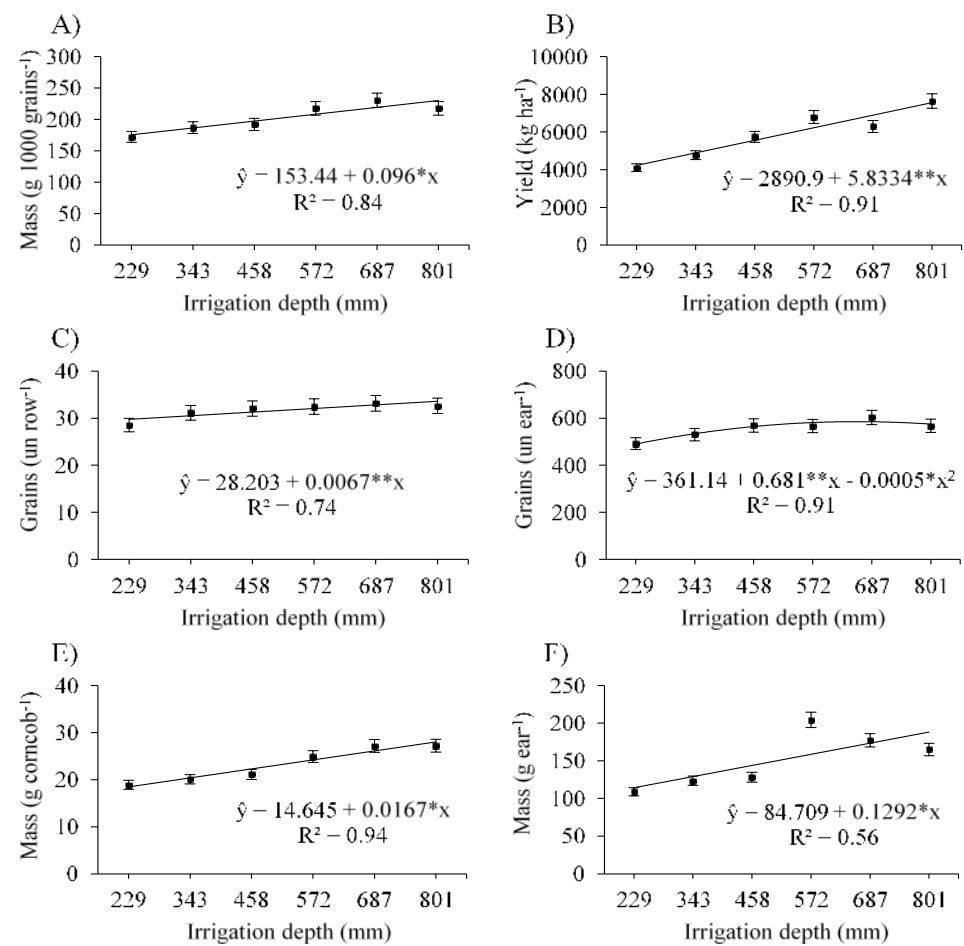

Fig 1. Production components: mass of a thousand grains (A), dry grain yield (B), grain number per row (C), grain number per ear (D), corncob mass $(\mathrm{E})$ and mass of dehusked corn ear $(\mathrm{F})$ under irrigation depths, in second experiment $\left(\mathrm{E}_{2}=\right.$ experiment 2 , from $25 / 08 / 2015$ to $25 / 12 / 2015)$. 
Table 2. Eigenvalues greater than the unity, portion of the explained variance, and correlation coefficients between the principal components and 12 variables.

\begin{tabular}{|c|c|c|c|c|c|c|c|c|c|c|c|c|c|c|}
\hline \multirow{2}{*}{ PCs } & \multirow{2}{*}{$\lambda$} & \multirow{2}{*}{$\sigma^{2} \%$} & \multicolumn{12}{|c|}{ Variable loadings (r) } \\
\hline & & & MTG & ENP & DGY & EAL & EAD & RNE & GNR & GNE & GME & CMA & MDE & STM \\
\hline PC1 & 7.36 & 61.34 & $-0.96^{*}$ & -0.56 & $-0.98^{*}$ & $-0.83^{*}$ & $-0.92^{*}$ & -0.46 & -0.33 & -0.57 & $-0.96^{*}$ & $-0.96^{*}$ & $-0.97^{*}$ & -0.42 \\
\hline $\mathrm{PC} 2$ & 1.82 & 15.16 & -0.24 & -0.04 & -0.13 & 0.36 & -0.30 & 0.25 & $0.85^{*}$ & $0.80^{*}$ & -0.11 & -0.23 & -0.12 & -0.14 \\
\hline PC3 & 1.45 & 12.06 & 0.03 & $-0.71^{*}$ & -0.08 & -0.21 & 0.07 & 0.59 & -0.08 & 0.12 & -0.04 & 0.03 & -0.05 & $0.72^{*}$ \\
\hline
\end{tabular}

PCs: principal components; $\lambda$ : eigenvalues; $\sigma^{2} \%$ : portion of explained variance; *: expressive correlation coefficient between the variable and the PC.
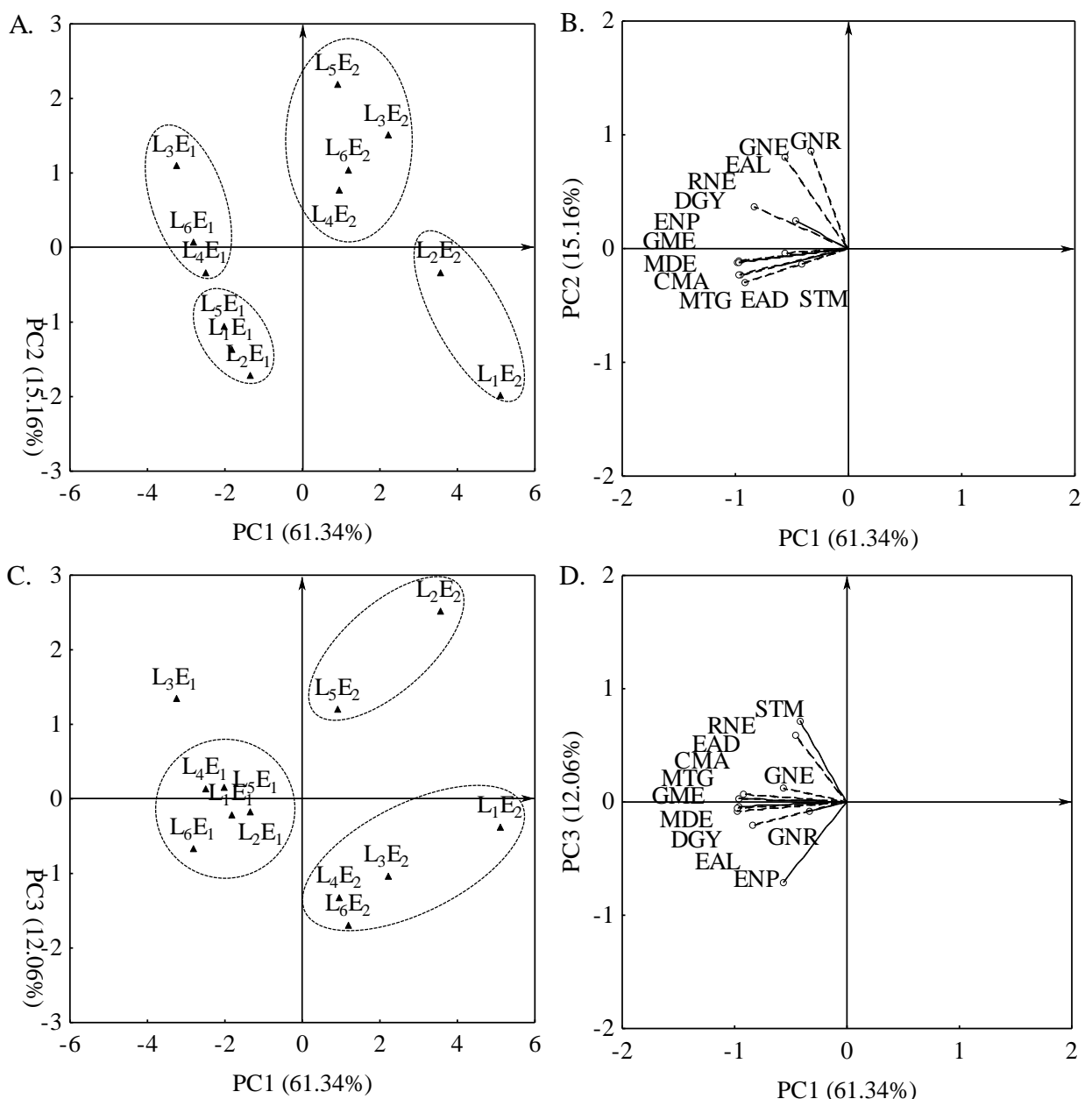

Fig 2. Dimensional projection of irrigation (L), experimental periods (E) and of 12 variables in principal components $1 \times 2$ (A and $B$ ) and $3 \mathrm{x} 1\left(\mathrm{C}\right.$ and D). $\mathrm{L}_{1} \mathrm{E}_{1}=19 \mathrm{~mm}, \mathrm{~L}_{2} \mathrm{E}_{1}=28 \mathrm{~mm}, \mathrm{~L}_{3} \mathrm{E}_{1}=38 \mathrm{~mm}, \mathrm{~L}_{4} \mathrm{E}_{1}=47 \mathrm{~mm}, \mathrm{~L}_{5} \mathrm{E}_{1}=56 \mathrm{~mm}, \mathrm{~L}_{6} \mathrm{E}_{1}=66 \mathrm{~mm}, \mathrm{~L}_{1} \mathrm{E}_{2}=229 \mathrm{~mm}, \mathrm{~L}_{2} \mathrm{E}_{2}=343$ $\mathrm{mm}, \mathrm{L}_{3} \mathrm{E}_{2}=458 \mathrm{~mm}, \mathrm{~L}_{4} \mathrm{E}_{2}=572 \mathrm{~mm}, \mathrm{~L}_{5} \mathrm{E}_{2}=687 \mathrm{~mm}, \mathrm{~L}_{6} \mathrm{E}_{2}=801 \mathrm{~mm}, \mathrm{E}_{1}=11 / 04 / 2015-11 / 08 / 2015, \mathrm{E}_{2}=25 / 08 / 2015-25 / 12 / 2015$.

Table 3. Efficiency of water use $\left(\mathrm{kg} \mathrm{m}^{-3}\right)$ by corn under irrigation depths.

\begin{tabular}{|c|c|c|c|c|c|c|c|c|c|}
\hline \multirow{3}{*}{ Efficiency } & \multicolumn{9}{|c|}{ First Experimental Period } \\
\hline & \multicolumn{6}{|c|}{ Irrigation depths $\left(\mathrm{m}^{3} \mathrm{ha}^{-1}\right)$} & \multicolumn{3}{|c|}{ Regression adjustment } \\
\hline & 19 & 28 & 38 & 47 & 56 & 66 & $\alpha$ & $\beta x_{i}$ & $\mathrm{R}^{2}$ \\
\hline$\overline{\mathrm{EWU}_{\mathrm{DM}}}$ & 5.95 & 5.62 & 5.80 & 5.20 & 5.91 & 5.86 & 5.74 & $-5 \mathrm{E}-4^{\mathrm{ns}}$ & $1 \mathrm{E}-3$ \\
\hline \multirow[t]{3}{*}{$\underline{\mathrm{EWU}_{\mathrm{GY}}}$} & 2.69 & 2.58 & 2.70 & 2.51 & 2.38 & 2.59 & 2,74 & $-3 \mathrm{E}-3^{\mathrm{ns}}$ & 0.32 \\
\hline & \multicolumn{9}{|c|}{ Second Experimental Period } \\
\hline & 229 & 343 & 458 & 572 & 687 & 801 & $\alpha$ & $\beta x_{i}$ & $\mathrm{R}^{2}$ \\
\hline$\overline{\mathrm{EWU}_{\mathrm{DM}}}$ & 3.87 & 3.21 & 3.30 & 2.74 & 2.49 & 2.51 & 4.24 & $-2 \mathrm{E}-3^{* *}$ & 0.89 \\
\hline $\mathrm{EWU}_{\mathrm{GY}}$ & 1.01 & 0.95 & 0.95 & 1.35 & 1.00 & 0.85 & 1.06 & $-5 \mathrm{E}-5^{\mathrm{ns}}$ & $5 \mathrm{E}-3$ \\
\hline
\end{tabular}

EWU: water use efficiency, DM: total dry matter of plants, GY: dry grain yield, $\alpha$ : population intercept, $\beta$ : population tilt, $x_{i}$ : independent variable, $\mathrm{R}^{2}$ : coefficient of determination, **: significant at $1 \%$ of probability $(p<0.01)$ and ns: not significant $(p>0.05)$ by t test. 
Table 4. Climate variables obtained during the periods of experiment execution.

\begin{tabular}{|c|c|c|c|c|c|c|c|c|c|c|c|}
\hline \multirow{2}{*}{ Months } & \multicolumn{3}{|c|}{ Temperature $\left({ }^{\circ} \mathrm{C}\right)$} & \multicolumn{3}{|c|}{ Relative air humidity (\%) } & \multicolumn{3}{|c|}{ Radiation $\left(\mathrm{MJ} \mathrm{m}^{-2}\right)$} & \multirow{2}{*}{$\begin{array}{l}\text { Rainfall } \\
\text { PP }(\mathrm{mm})\end{array}$} & \multirow{2}{*}{$\begin{array}{c}\text { Evaporation } \\
\mathrm{ET}_{0}(\mathrm{~mm})\end{array}$} \\
\hline & Average & High & Low & Average & High & Low & $\mathrm{Rg}$ & PAR & $\mathrm{Rn}$ & & \\
\hline$\overline{\text { April }}$ & 30.30 & 36.52 & 24.08 & 59.10 & 87.55 & 30.65 & 21.95 & 9.22 & 12.56 & 4.60 & 5.80 \\
\hline May & 28.87 & 34.63 & 23.11 & 62.95 & 90.52 & 35.39 & 8.58 & 7.80 & 10.63 & 25.80 & 4.93 \\
\hline June & 26.13 & 30.49 & 21.77 & 74.18 & 96.17 & 52.20 & 15.12 & 6.35 & 8.72 & 10 & 3.38 \\
\hline July & 25.20 & 29.36 & 21.03 & 76.60 & 97.84 & 55.35 & 16.11 & 6.77 & 9.22 & 92.20 & 3.28 \\
\hline August & 26.16 & 33.44 & 18.89 & 63.93 & 96.57 & 31.29 & 21.80 & 9.15 & 12.47 & 0.00 & 5.20 \\
\hline September & 27.38 & 34.18 & 20.59 & 62.72 & 93.90 & 31.53 & 22.38 & 9.40 & 12.80 & 22.60 & 5.60 \\
\hline October & 28.56 & 35.40 & 21.73 & 58.98 & 88.61 & 29.35 & 23.93 & 10.05 & 13.69 & 10.00 & 6.19 \\
\hline November & 30.50 & 38.08 & 22.91 & 52.82 & 83.57 & 22.07 & 26.53 & 11.14 & 15.17 & 0.20 & 7.06 \\
\hline December & 30.48 & 37.24 & 23.73 & 55.82 & 85.40 & 26.24 & 24.56 & 10.32 & 14.06 & 18.00 & 6.61 \\
\hline
\end{tabular}

Rg: global radiation, PAR: photosynthetically active radiation, Rn: radiation balance and PP: rainfall, $\mathrm{ET}_{0}$ : evapotranspiration of reference.

Table 5. Physical and chemical attributes of the experimental area in the first experiments

\begin{tabular}{|c|c|c|c|c|}
\hline \multirow{2}{*}{ Layers } & \multicolumn{4}{|l|}{ Attributes } \\
\hline & Sandy (\%) & Silt (\%) & Clay (\%) & Texture \\
\hline $0.00-0.30 \mathrm{~m}$ & 60.58 & 26.50 & 12.92 & $\mathrm{FA}^{1}$ \\
\hline \multirow[t]{2}{*}{$0.30-0.60 \mathrm{~m}$} & 52.65 & 42.61 & 4.74 & $\mathrm{FA}^{1}$ \\
\hline & $\mathrm{FC}\left(\mathrm{cm}^{3} \mathrm{~cm}^{-3}\right)$ & $\operatorname{PWP}\left(\mathrm{cm}^{3} \mathrm{~cm}^{-3}\right)$ & Density $\left(\mathrm{g} \mathrm{cm}^{-3}\right)$ & Porosity $(\%)$ \\
\hline $0.00-0.30 \mathrm{~m}$ & 22.61 & 6.43 & 1.39 & 48.13 \\
\hline \multirow[t]{2}{*}{$0.30-0.60 \mathrm{~m}$} & 26.47 & 6.45 & 1.41 & 47.78 \\
\hline & $\mathrm{pH} \mathrm{KCl}(1: 2.5)$ & $\mathrm{OM}(\%)$ & $\mathrm{P}(\mathrm{ppm})$ & $\mathrm{K}(\mathrm{ppm})$ \\
\hline $0.00-0.30 \mathrm{~m}$ & 6.54 & 1.07 & 31.00 & 76.00 \\
\hline $0.30-0.60 \mathrm{~m}$ & 5.95 & 0.93 & 13.00 & 43.00 \\
\hline
\end{tabular}

${ }^{1}$ Sandy loam, PWP: permanent wilting point, FC: field capacity, OM: organic matter.

especially in tropical regions (Keller Filho et al., 2006). In this sense, local agriculture is commonly practiced in the rainy season. However, one way to cultivate in the dry season is to use irrigation, and there is a need to study the water depth appropriate to the crop (Carvalho et al., 2013). It is believed that in the first experiment with emphasis on rainfall, the combination of environmental factors have provided optimal growth environment, overcoming the effect of the treatments.

An increase in production components of corn in response to increase irrigation depths was expected in the conditions, under which the experiment was conducted. The experimental area was located in a semiarid region and characterized by a temporal and spatial limitation of water resources, requiring the use of irrigation depths to meet the crop demand (Silva et al., 2015). It is noteworthy that the use of irrigation along with naturally precipitated water is a significant management strategy in corn crops to water deficiency in crucial stages of development and production (Ribeiro et al., 2015).

As corn is very demanding and has a high water demand, the water supply in larger amounts resulting from irrigation depths helped to increase soil moisture and met the crop need entirety to furnish a greater production (Silva et al., 2012; Xavier et al., 2014). Even irrigation with smaller depths may produce higher dry grain yield than the national average $\left(3,620 \mathrm{~kg} \mathrm{ha}^{-1}\right)$. The larger depths has produced values greater than the average productivity of China $\left(5,560 \mathrm{~kg} \mathrm{ha}^{-1}\right)$, although below the average yield of the United States, of $9,660 \mathrm{~kg} \mathrm{ha}^{-1}$ (Ribeiro et al., 2015).

Minuzzi and Lopes (2015) reported that climate is the main factor related to the production of corn. Thus, the more pronounced responses in the production components occurred in the second experimental period $\left(\mathrm{E}_{2}\right)$ are associated with the specific climatic variables, especially the low rainfall $(78.0 \%$ lower than $E_{1}$ ), the global radiation $(\mathrm{Rg})$, photosynthetically active radiation (PAR), and radiation balance (Rn), which had increases of $21.5 \%, 21.5 \%$ and $21.4 \%$, respectively. These factors promoted an increase of $4.5 \%$ in the average atmosphere temperature and a reduction of $12.6 \%$ in relative air humidity, such that the combination of these factors contributed to an increase of $26.3 \%$ in crop evapotranspiration in $\mathrm{E}_{1}$ (Table 4). The low productivity occurred in plants in $E_{2}$, irrigated with smaller depths, is related to the lower availability of water in the soil and consequent hydric stress. Usually, the water deficit causes reduction of the photosynthetic apparatus, $\mathrm{CO}_{2}$ assimilation, and biomass allocation, stimulating increased accumulation of soluble sugars in the leaves and a decrease in the amount of starch (Costa et al., 2008; Minuzzi and Lopes, 2015).

Melo et al. (2010) reported that if water deficit occurs in the critical period, the recovery of the productive capacity of the culture will not be satisfactory and the final production will be severely reduced. In a complementary sense, Bergamaschi et al. (2006) mentioned that the most severe reductions in production occur due to water deficit in the stages of pollination, zygote formation, and early development of the grain.

The production components vary in the function of photosynthetic dynamics. Therefore, under moderate water deficit, there is a decrease in the photosynthetic rate. However, the light reactions, transport of electrons, and reduction of $\mathrm{NADP}^{+}$are retained, causing an energy imbalance (Lawlor and Tezara, 2009). This may result in synthesis of the reactive oxygen species (ROS) that damage the ATP synthase enzyme, delaying the synthesis of ribulose1,5-bisphosphate (RuBP) and causing a decrease in Ribulose-1,5-bisphosphate carboxylase/oxygenase (rubisco) activity. These are physiological events reflected as lower yield and production components, at lower irrigation depths (Chavarria et al., 2015).

In a space with smaller dimensions, the reduction of the multi-dimensional space of the data from these experiments sets an important strategy for a better understanding of the results. It is an important auxiliary tool for making decisions on corn crops irrigated with variable water depths. In fact, to analyze and understand complex studies is a challenging task, especially due to the high volume of data involved and the occurrence of multicollinearity between variables, emphasizing the use of multivariate analysis. For example, 
Principal Component Analysis can be used as an efficient tool to mitigate these difficulties (Ranamukhaarachchi et al., 2017; Yi et al., 2017).

It should be noted that the corn is characterized by its great requirement to water and also for its most efficient water use (WUE) as well. In other words, it has a high ratio of dry matter production by absorbed water unit (Silva et al., 2012). Therefore, its stability in the WUE in the first experimental period can be explained by the high volume of precipitation and the complementation of the required water through irrigation. The reduction of $\mathrm{EWU}_{\mathrm{DM}}$ in the second experimental period is linked to the climatic characteristics and to the physiological responses of the plants. In another aspect, the adopted planting system may have contributed to the maintenance of soil moisture and better use of water, even at smaller irrigation depths. This information is ratified by Murga-Orrillo et al. (2016), who found that the greatest WUE can occur in covered soil.

In a research with irrigation depths, Souza et al. (2011) obtained values higher than the ones observed in this study. The authors justified the gain in WUE because the cultivar had been improved for adaptation in semiarid conditions. However, the WUE values found in this study are similar to those reported by Minuzzi and Lopes (2015), who estimated the WUE values of corn in different climate scenarios in the Midwest of Brazil and found for the current conditions, values of $2.8 \mathrm{~kg} \mathrm{~m}^{-3}$ (Catalão - GO), $2.61 \mathrm{kgm}^{-3}$ (Rio Verde GO), $2.99 \mathrm{~kg} \mathrm{~m}^{-3}$ (Ponta Porã - MS), $2.91 \mathrm{~kg} \mathrm{~m}^{-3}$ (Invinhema - MS), and $2.43 \mathrm{~kg} \mathrm{~m}^{-3}$ (Diamantino - MT).

\section{Materials and Methods}

\section{Experimental area characterization}

Due to the transition between the dry and rainy period and characteristic of the region, there is a dry and a rainy season. It is necessary to identify the appropriate irrigation depth for the maize crop in each period. Thus, two experiments were conducted at two different periods, the first period $\left(\mathrm{E}_{1}\right)$ was conducted in the period between April and August 2015 and the second period $\left(\mathrm{E}_{2}\right)$, between August and December of the same year. The experimental area was located in the Farm Tororó III, Pão de Açúcar municipality, state of Alagoas (AL) on the coordinates of latitude: $09^{\circ} 45^{\prime} 20.7$ ' S, longitude: $37^{\circ} 25^{\prime} \quad 1 \quad 2.3^{\prime} \mathrm{W}$, and an altitude of $18 \mathrm{~m}$. According to the Köeppen classification (1948), the local climate was classified as BSh', with a predominance of hypoxerophytic caatinga. It presents an average annual air temperature of $27^{\circ} \mathrm{C}$ and average annual rainfall of $500 \mathrm{~mm}$ (Barros et al., 2012).

During the period of conducting the research, climate monitoring was performed and expressed through agroclimatic variables obtained from the automatic weather station of the National Institute of Meteorology-INMET (latitude: $09^{\circ} 44^{\prime} 56^{\prime \prime} \mathrm{S}$, longitude: $37^{\circ} 25^{\prime} 51^{\prime} \mathrm{W}$ and altitude of $15 \mathrm{~m}$ ) located $1.6 \mathrm{~km}$ from the experimental area. The monthly averages are presented in Table 4 .

In the experimental area, prior to assembly of the first experiment, 12 simple soil samples were collected in layers from a depth of 0.00 to $0.30 \mathrm{~m}$ and 0.30 to $0.60 \mathrm{~m}$. These were composite samples representative of each depth. The samples were properly packed and sent to the Laboratory of Irrigation and Salinity of the Federal University of Campina Grande for analysis of their physical and chemical properties (Table 5).

The water used in the experiments came through a flume from the São Francisco river, which was at a distance of 113 $\mathrm{m}$ from the experimental area. Water samples of $1 \mathrm{~L}$ were collected from around the pickup point, packed into water containers, washed thrice with the water collected, and then forwarded to the Central Analytical Laboratory in the city of Maceió, state of AL, for chemical and salinity analysis. The following values were recorded: $\mathrm{pH}=8.15, \mathrm{Ca}=0.44 \mathrm{mmol}_{\mathrm{c}}$ $\mathrm{L}^{-1}, \mathrm{Mg}=0.16 \mathrm{mmol}_{\mathrm{c}} \mathrm{L}^{-1}, \mathrm{Na}=0.88 \mathrm{mmol}_{\mathrm{c}} \mathrm{L}^{-1}, \mathrm{~K}=0.03$ $\mathrm{mmol}_{\mathrm{c}} \mathrm{L}^{-1}, \mathrm{Fe}=0.08 \mathrm{ppm}$, Electrical Conductivity $=0.16 \mathrm{dS}$ $\mathrm{m}^{-1}$, Carbonates $=0.00 \mathrm{mmol}_{\mathrm{c}} \mathrm{L}^{-1}$, Bicarbonates $=0.32 \mathrm{mmol}_{\mathrm{c}}$ $\mathrm{L}^{-1}$, Chlorides $=0.89 \mathrm{mmol}_{\mathrm{c}} \mathrm{L}^{-1}$, Sulfates $=0.35 \mathrm{mmol}_{\mathrm{c}} \mathrm{L}^{-1}$, Sodium Adsorption Ratio $=1.54$, Class $=$ C1-S1, General Classification $=$ No Restriction .

\section{Experimental design}

The experimental design was randomized blocks, with six treatments (water depths), corresponding to 50\%, 75\%, $100 \%, 125 \%, 150 \%$, and $175 \%$ replacement of evapotranspirated water $\left(\mathrm{ET}_{0}\right)$, with four replications.

\section{Area preparation}

The total experimental area $\left(480 \mathrm{~m}^{2}\right)$ was cultivated with a No-Till System, performing desiccation of the vegetation cover with application of $1 \mathrm{~L} \mathrm{ha}^{-1}\left(0.48 \mathrm{~kg}\right.$ i.a. ha $\left.{ }^{-1}\right)$ of Glyphosate, 15 days before sowing. Each experimental plot occupied an area of $20.0 \mathrm{~m}^{2}(5.0 \mathrm{~m} \times 4.0 \mathrm{~m})$, consisting of five irrigation lines, $5.0 \mathrm{~m}$ in length, with spacing of $0.80 \mathrm{~m}$ between lines, and $0.20 \mathrm{~m}$ between plants. At harvest, a row of each extremity of the plot (border) was discarded, collecting a useful area of $12 \mathrm{~m}^{2}$.

Soil fertilization was performed by the interpretation of the soil analysis, applying $45 \mathrm{~kg} \mathrm{ha}^{-1}$ of $\mathrm{N}_{2}, 138 \mathrm{~kg} \mathrm{ha}^{-1} \mathrm{P}_{2} \mathrm{O}_{5}$, and $37 \mathrm{~kg} \mathrm{ha}^{-1}$ of $\mathrm{K}_{2} \mathrm{O}$.

A localized irrigation drip system was used, consisting of drip tape with $16 \mathrm{~mm}$ nominal diameter, with flow emitters of $7.5 \mathrm{~L} \mathrm{~h}^{-1}$ spaced at every $0.20 \mathrm{~m}$, operating under a service pressure of $10 \mathrm{mH}_{2} \mathrm{O}$ (meters of water column). For system automation, a set of six electrovalves was adopted, which was activated by a programmer, for six stations.

\section{Seeding}

The sowing of corn, hybrid AG 7088 from Agroceres, was performed in both experiments $\left(\mathrm{E}_{1}=\right.$ experiment 1 from $11 / 04 / 2015$ to $11 / 08 / 2015$ and $E_{2}=$ experiment 2 , from $25 / 08 / 2015$ to $25 / 12 / 2015$ ), adopting three seeds evenly distributed. 10 days after sowing (DAS), thinning was carried out by adopting one plant per pit, totalizing the final stand of 62,500 plants $\mathrm{ha}^{-1}$. During 15 DAS, the soil was maintained under daily irrigation with $12.5 \mathrm{~mm}$. This was considered to be sufficient time for seedling establishment in the field.

\section{Treatment application}

The application of irrigation depths corresponding to the treatments was carried out with a frequency of two days, performed based on the restoration of evapotranspirated water $\left(\mathrm{ET}_{0}\right)$ and calculated by summing the $\mathrm{ET}_{0}$ of two days, prior to the day of irrigation. On the days of recorded rainfall during the crop cycle, the same was subtracted from the $\mathrm{ET}_{0}$. For the calculation of daily $\mathrm{ET}_{0}$, the FAO Penman-Monteith method was used (Allen, 1989).

The time required for repositioning of the respective depths was recorded by the programmer to activate and stop the operation of the irrigation system. 
At the end of the first experiment, the total depths corresponded to $\mathrm{L}_{1}=19 \mathrm{~mm}, \mathrm{~L}_{2}=28 \mathrm{~mm}, \mathrm{~L}_{3}=38 \mathrm{~mm}, \mathrm{~L}_{4}=$ $47 \mathrm{~mm}, \mathrm{~L}_{5}=56 \mathrm{~mm}$, and $\mathrm{L}_{6}=66 \mathrm{~mm}$; and at the end of the second experiment $\mathrm{L}_{1}=229 \mathrm{~mm}, \mathrm{~L}_{2}=343 \mathrm{~mm}, \mathrm{~L}_{3}=458$ $\mathrm{mm}, \mathrm{L}_{4}=572 \mathrm{~mm}, \mathrm{~L}_{5}=687 \mathrm{~mm}$, and $\mathrm{L}_{6}=801 \mathrm{~mm}$.

\section{Field management}

Soon after sowing, 4.0 $\mathrm{L} \mathrm{ha}^{-1}$ of the pre-emergent selective herbicide Primestra Gold ${ }^{\circledR}$ (Syngenta Crop Protection Ltda) was applied. The first top dressing of the crop occurred 22 days after sowing (DAS), with $112 \mathrm{~kg} \mathrm{ha}^{-1}$ of urea $\left(45 \% \mathrm{~N}_{2}\right)$. At 25 DAS, in order to control the Cartridge worm (Spodoptera frugiperda L.), $150 \mathrm{ml} \mathrm{ha}^{-1}$ of insecticide Karatê Zeon $50 \mathrm{CS}^{\circledR}$ (Syngenta Crop Protection Ltda) was applied. On completion $30 \mathrm{DAS}, 0.5 \mathrm{~L}$ of the herbicide Roundup Original $^{\circledR}$ (Monsanto from Brazil Ltda) per $100 \mathrm{~L}$ of water was applied to control weeds with a directed jet between the lines of plantation. The second top dressing was performed at 54 DAS, with $112 \mathrm{~kg} \mathrm{ha}^{-1}$ of urea $\left(45 \% \mathrm{~N}_{2}\right)$. At $35 \mathrm{DAS}$, some insects like bumble bees botflies (Dermatobia hominis) and wood saw beetles (Oncideres impluviata) were emerged in the experimental area and were controlled with one application of the insecticide Connect ${ }^{\circledR}$ (Bayer S/A) at a dose of $750 \mathrm{ml} \mathrm{ha}^{-1}$.

\section{Evaluated variables}

After 120 DAS, finalizing maturity, the useful area was manually harvested in portions, which corresponded to the three lines of the interior plot, being $3 \mathrm{~m}$ from the central line and $1.5 \mathrm{~m}$ from the side lines. The production components of corn were expressed through the variables: mass of a thousand grains (MTG g 1000 grains $^{-1}$ ), ear number per plot (ENP un plot $^{-1}$ ), dry grain yield (DGY kg ha ${ }^{-1}$ ), ear length $\left(\mathrm{EAL} \mathrm{cm} \mathrm{ear}^{-1}\right.$ ), ear diameter (EAD mm ear ${ }^{-1}$ ), row number per ear (RNE un ear ${ }^{-1}$ ), grain number per row (GNR un line ${ }^{-}$ ${ }^{1}$ ), grain number per ear (GNE un ear $\left.{ }^{-1}\right)$, grain mass per ear (GME g ear-1), corn cob mass (CMA g corncob ${ }^{-1}$ ), mass of dehusked ear (MDE $g$ ear ${ }^{-1}$ ), and ear straw mass (STM g) of corn.

The agronomic efficiency of water use (WUE) was estimated according to the methodology of Faraco et al. (2016), being expressed in terms of dry matter $\left(\mathrm{WUE}_{\mathrm{DM}}\right)$ and grain yield $\left(\mathrm{WUE}_{\mathrm{GY}}\right)$. For this purpose, the $\mathrm{EWU}_{\mathrm{DM}}$ was calculated using the ratio between the total dry matter production $\left(\mathrm{kg} \mathrm{ha}^{-1}\right)$ and the consumed water volume $\left(\mathrm{m}^{3} \mathrm{ha}^{-}\right.$ ${ }^{1}$ ), while the $\mathrm{WUE}_{\mathrm{GY}}$ was obtained by using the ratio between the obtained grain yield $\left(\mathrm{kg} \mathrm{ha}^{-1}\right)$ and the consumed water volume $\left(\mathrm{m}^{3} \mathrm{ha}^{-1}\right)$. The WUE was expressed in kilograms of dry matter or corn grains per cubic meter of water $\left(\mathrm{kg} \mathrm{m}^{-3}\right)$. It is important to note that, due to the nature of this variable, it was not included in the database for statistical analysis, avoiding multicollinearity and redundant results (Guilhen et al., 2016; Lindner and Pitombo, 2016).

\section{Statistical analysis}

The original data were submitted to univariate variance analysis and when a difference was found between the treatments, we used the polynomial regression analysis to show the best estimated irrigation depths (Barbosa and Maldonado Júnior, 2015). Subsequently, the data were standardized to make zero mean and unitary variance. The multivariate structure of the results was evaluated by means of exploratory Principal Component Analysis (PCA), condensing the amount of relevant information in the original set of data into a smaller number of dimensions, resulting in linear combinations of the original variables generated from the highest eigenvalues in the covariance matrix (Hair et al., 2009).

\section{Conclusion}

The production components and water use efficiency of corn hybrid AG 7088 were not affected by varying water depths in the first experimental period. In the second experimental period, an increase of irrigation depth promoted significant gains in the mass of a thousand grains, dry grain yield, grain number per row, grain number per corn ear, corncob mass, and mass of the dehusked ear, reducing the water use efficiency. The use of multivariate analysis of Principal Components was effective in reducing the multidimensional space of the original set of variables in three dimensions, with relevant information to highlight the differences between irrigation depths and experimental periods.

\section{Acknowledgments}

The authors thank the Federal Institute of Alagoas - IFAL and the Coordination of Improvement of Higher Education Personnel (CAPES).

\section{References}

Alderfasi AA, Selim MM, Alhammad BA (2016) Evaluation of plant densities and various irrigation regimes of sorghum (Sorghum bicolor L.) under low water supply. J Water Resource Prot. 8:1-11.

Allen RG, Pereira, LS, Raes D, Smith M (1998) Crop evapotranspiration-guidelines for computing crop water requirements-FAO Irrigation and drainage paper 56. FAO, Rome, 300(9):D05109.

Barbosa JC, Maldonado Júnior W (2015) Experimentação agronômica \& agroestat - sistema para análises estatísticas de ensaios agronômicos. Jaboticabal: Funep 396 p.

Barros AHC, Araújo Filho JC, Silva AB, Santiago GACF (2012) Climatologia do estado de Alagoas. Boletim de Pesquisa e Desenvolvimento. Recife: Embrapa Solos 32 p.

Bergamaschi H, Dalmago GA, Comiran F, Bergonci JI, Müller AG, França S, Santos AO, Radin B, Bianchi CAM, Pereira PG (2006) Déficit hídrico e produtividade na cultura do milho. Pesqui Agropecu Bras. 41:243-249.

Carvalho AL, Souza JL, Lira GB, Silva EC (2013) Estação chuvosa e de cultivo para a região de Rio Largo, Alagoas baseada em métodos diretos e sua relação com o El Niño Oscilação Sul. Rev Bras Meteorol. 28:192-198.

Chavarria G, Durigon MR, Klein VA, Kleber H (2015) Restrição fotossintética de plantas de soja sob variação de disponibilidade hídrica. Ciênc Rural. 45:1387-1393.

Costa JR, Pinho JLN, Parry MM (2008) Produção de matéria seca de cultivares de milho sob diferentes níveis de estresse hídrico. Rev Bra Eng Agr Amb. 12:443-450.

Dancey C, Reidy J (2013) Estatística sem matemática para psicologia. Porto Alegre: Artmed 608 p.

Dantas Júnior EE, Garófalo LH, Costa FAM, Korndorfer GH (2011) Desenvolvimento de milho irrigado e adubado com silicato de cálcio e magnésio. Rev Bra Agric Irri. 5: $337-$ 350.

Faraco JR, Castro NMR, Louzada JA, Silva PRF, Schoenfeld R, Maass MB, Pagliarini N (2016) Rendimento de grãos e eficiência do uso de água da cultura do milho em áreas de cultivo de arroz inundado com difrente manejo de irrigação e drenagem. Irriga. 1:274-290. 
Guilhen JHS, Marçal TS, Zanotti RF, Lopes JC, Ferreira A (2016) Physiological characteristics in seeds of the common bean under multicollinearity and conditions of salinity. Rev Ciênc Agron. 47:127-134.

Hair FJ, Black WC, Babin BJ, Anderson RE, Tatham RL (2009) Análise Multivariada de Dados. Porto Alegre: Bookman 688 p.

Keller Filho T, Zullo Junior J, Lima PRSR (2006) Análise da transição entre dias secos e chuvosos usando cadeias de Markov de terceira ordem. Pesqui Agropecu Bras. 41:13411349.

Köppen W (1948) Climatologia: con un estudio de los climas de la tierra: Fondo de Cultura Econômica. México: Editora $479 \mathrm{p}$.

Lawlor DW, Tezara W (2009) Causes of decreased photosynthetic rate and metabolic capacity in waterdeficientleaf cells: a critical evaluation of mechanisms and integration of processes. Ann Bot. 103:561-579, 2009.

Lindner A, Pitombo CS (2016) Modelo logit binomial com componentes principais para estimação de preferência por modo de transporte motorizado. J Transp Lit. 10:5-9.

Li Z, Sun Z (2016) Optimized single irrigation can achieve high corn yield and water useefficiency in the Corn Belt of Northeast China. Eur J Agron. 75:12-24.

Melo TM, Wottrich I, Louzada JA, Helfer F (2010) Avaliação do atendimento da demanda hídrica da cultura do milho através da subirrigação. Rev Bra Agric Irri. 4:226-233.

Minuzzi RB, Lopes FZ (2015) Desempenho agronômico do milho em diferentes cenários climáticos no Centro-Oeste do Brasil. Rev Bra Eng Agr Amb. 19:734-740.

Murga-Orrillo H, Araújo WF, Abanto-Rodriguez C, Sakazaki RT, Bardalez Lozano RM, Polo-Vargas AR (2016) Influência da cobertura morta na evapotranspiração, coeficiente de cultivo e eficiência de uso de água do milho cultivado em cerrado. Irriga. 21:352-364.
Ranamukhaarachchi SA, Peiris RH, Moresoli C (2017) Fluorescence spectroscopy and principal component analysis of soyprotein hydrolysate fractions and the potential to assess theirantioxidant capacity characteristics. Food Chem. 217:469-475.

Ribeiro RB, Carvalho CM, Feitosa HO, Feitosa SO, Silva SL (2015) Crescimento do milho BRS catingueiro irrigado no cariri cearense. Appl Res Agrotec. 8:81-86.

Silva JN, Linhares PCA, Figueredo, JP, Irineu THS, Silva JN, Andrade R (2015) Crescimento do milho bandeirante sob lâminas de irrigação e mulching. Agropec Cient Sem. 11:87-96

Silva MRR, Vanzela LS, Vazquez GH, Sanches AC (2012) Influência da irrigação e cobertura morta do solo sobre as características agronômicas e produtividade de milho. Irriga. 1:170-180.

Souza LSB, Moura MSB, Sediyama GC, Silva TGF (2011) Eficiência do uso da água das culturas do milho e do feijãocaupi sob sistemas de plantio exclusivo e consorciado no semiárido brasileiro. Bragantia. 70:715-721.

Wu G, Johnson S, Bornman JF, Bennett SJ, Fang Z (2017) Changes in whole grain polyphenols and antioxidant activity of six sorghum genotypes under different irrigation treatments. Food Chem. 214: 199-207.

Xavier DA, Furtado GF, Sousa Júnior JR, Sousa JRM, Andrade EMG (2014) Produção de fitomassa do milho sob lâminas de irrigação e adubação nitrogenada. Rev Ver Agr Des Susten. 9:144-148.

Yi S, Lai Z, He Z, Cheung Y, Liu Y (2017) Joint sparse principal component analysis. Pattern Recognit. 61:524536. 